\title{
KONSTRUKSI MODEL FAKTOR ANTESEDEN LOYALITAS BERBASIS NILAI PELANGGAN
}

\author{
Irwan Christanto Edy \\ STIE 'Adi Unggul Bhirawa' Surakarta, Indonesia \\ Email: irwan_aub@yahoo.co.id
}

\begin{abstract}
Abstrak: Konstruksi Model Faktor Anteseden Loyalitas Berbasis Nilai Pelanggan. Tujuan Penelitian ini adalah menguji model konseptual pengaruh nilai pelanggan terhadap loyalitas melalui kepuasan, pelayanan purna jual, kepercayaan pada merk dan pemasaran relasional. Penelitian ini merupakan penelitian survai. Data yang digunakan adalah data primer dengan mengambil nasabah sebagai objek penelitian. Instrumen pengumpulan data berupa daftar pertanyaan (kuesioner) baik dengan pertanyaan terbuka maupun tertutup. Metode analisis data yang digunakan meliputi analisis uji instrumen, analisis statistik deskriptif, dan analisis SEM. Model konseptual yang menggambarkan hubungan nilai pelanggan terhadap loyalitas melalui kepuasan, pelayanan purna jual, kepercayaan pada merk dan pemasaran relasional dapat diterima secara empiris. Penelitian ini menemukan bahwa nilai pelanggan dan layanan purna jual memberi kontribusi langsung yang signifikan terhadap loyalitas pelanggan.
\end{abstract}

Kata Kunci: nilai pelanggan, loyalitas, pemasaran relasional

\begin{abstract}
Construction of Antecedent Factor Model of Customer Value-Based Loyalty. The study aims to test the conceptual model of the effect of customer value on customer loyalty through satisfaction, after sales service, trust the brand and relationship marketing. This study is a survey research. The data used are primary that motorcycles customers in the city of Surakarta, as research objects. Data collection instruments in the form of a list of questions (questionnaire) either the open or closed questions. Data analysis methods used include analysis instrument test, descriptive statistical analysis, and analysis of the SEM. The conceptual model that describes the relationship of the value of customer loyalty through satisfaction, after sales service, trust the brand and relationship marketing empirically acceptable (meets the criteria Goodness of fit) scientific. This study found that the value of the customer and aftersales services contribute direct and significant to customer loyalty
\end{abstract}

Keywords: customer value, loyalty, relationship marketing

\section{PENDAHULUAN}

Loyalitas adalah puncak pencapaian pelaku bisnis. Loyalitas merupakan basis penting dalam pengembangan bisnis. Perusahaan akan memperoleh manfaat yang besar dari nasabah yang memiliki loyalitas. Loyalitas diyakini disebabkan oleh kepuasan pelanggan (customer satisfaction), kualitas pelayanan yang dipersepsikan (perceived quality), nilai yang dipersepsikan (perceived value), kepercayaan (trust) dan komitmen (commitment) (Garbarino \& Johnson 1999). Penelitian terdahulu seperti Rasheed dan Abadi (2014), Kiran dan Dihjit (2010), Quach et al (2016), menunjukan bahwa kualitas pelayanan berpengaruh terhadap loyalitas pelanggan, namun penelitian yang mengkaitkan nilai pelanggan (kualitas pelayanan, produk dan harga) dengan loyalitas masih terbatas, justeru Chen (2015) mempertanyakan kembali hubungan nilai pelanggan dengan loyalitas. 
Penelitian terdahulu menjelaskan bahwa ada beberapa faktor lain yang mempengaruhi loyalitas pelanggan. Saparso dan Jesfer (2010) menjelaskan bahwa kepuasan pelanggan berpengaruh cukup kuat terhadap loyalitas pelanggan. Penelitian itu, didukung pula dengan penelitian yang dilakukan oleh Agung Mahendra Putra dan Penny Rahmawati (2012), yang menjelaskan bahwa kepuasan pelanggan berpengaruh positif terhadap loyalitas pelanggan sepeda motor Honda di Kota Yogyakarta. Penelitian Agung mahendra Putra dan Penny Rahmawati juga menjelaskan bahwa kepuasan pelanggan sebagai variabel mediasi belum mampu memediasi pengaruh ekuitas merek terhadap loyalitas pelanggan sepeda motor Honda di kota Yogyakarta karena pengaruh langsung kepuasan pelanggan ke loyalitas pelanggan lebih kecil daripada pengaruh langsung ekuitas merek ke loyalitas pelanggan. Sementara itu, Diana arief dkk (2012) menjelasakan bahwa layanan purna jual berpengaruh langsung dan signifikan terhadap kepuasan dan loyalitas pelanggan sepeda motor di kota Makasar. Muhammad Yodi Rizkiyardi (2013) juga mendukung hasil penelitian tersebut, yang menyatakan bahwa layanan purna jual berpengaruh signifikan terhadap loyalitas pelanggan mobil avans di Bekasi. Selain itu, penelitian Muhammad Rafig (2009) menyatakan bahwa kepercayaan pada merk mempunyai hubungan dengan loyalitas pelanggan sepeda motor honda di Bekasi. Penelitian lain, Liza Amalia Rizka (2010) menjelaskan bahwa 1) terdapat pengaruh yang signifikan antara pemasaran relasional (relationship marketing) (keuntungan bersama, kebenaran, komitmen dan komunikasi) secara parsial terhadap loyalitas pelanggan sepeda motor Yamaha, 2) terdapat pengaruh yang signifikan antara pemasaran relasional (relationship marketing) (keuntungan bersama, kebenaran, komitmen dan komunikasi) secara simultan terhadap loyalitas pelanggan sepeda motor Yamaha, 3) komunikasi PT Yamaha terhadap pelanggan sepeda motor Yamaha merupakan variabel dominan dalam membentuk loyalitas pelanggan. Berdasarkan research gap hasil penelitian antara Rasheed dan Abadi (2014), Kiran dan Dihjit (2010), Quach et al (2016) dan Chen (2015) maka kebaharuan dari penelitian ini adalah menguji ulang kontruksi model pengaruh nilai pelanggan terhadap loyalitas pelanggan dengan memperhatikan peran mediasi faktor pemasaran relasional, kepuasan pelanggan, layanan purna jual, kepercayaan pada merk. Pengujian secara empiris pada pelanggan sepeda motor pada dealer di Kota Surakarta. Penelitian ini dapat memberikan kontribusi baik secara teoritis maupun praktik.

Beberapa pakar manajemen telah memberikan pengertian tentang loyalitas. Ali Hasan (2008) menjelaskan loyalitas sebagai berikut: (1) Konsep generik, loyalitas menunjukkan kecenderungan konsumen untuk membeli sebuah merek tertentu dengan tingkat konsistensi yang tinggi. (2) Konsep perilaku, pembelian ulang kerap kali dihubungkan dengan loyalitas merek (brand loyality), bila loyalitas merek mencerminkan komitmen psikologis terhadap merek tertentu, perilaku pembelian ulang menyangkut pembelian merek yang sama secara berulang kali. Loyalitas pelanggan merupakan salah satu tujuan inti yang diupayakan dalam pemasaran modern. Hal 
ini dikarenakan dengan loyalitas diharapkan perusahaan akan mendapatkan keuntungan jangka panjang atas hubungan mutualisme yang terjalin dalam kurun waktu tertentu. Loyalitas merupakan sebuah sikap yang menjadi dorongan perilaku untuk melakukan pembelian produk/jasa dari suatu perusahaan yang menyertakan aspek perasaan di dalamnya, khususnya yang membeli secara teratur dan berulang-ulang dengan konsistensi yang tinggi, namun tidak hanya membeli ulang suatu barang dan jasa, tetapi juga mempunyai komitmen dan sikap yang positif terhadap perusahaan yang menawarkan produk/ jasa tersebut

Kotler (2009) menyatakan bahwa nilai pelanggan adalah selisih nilai pelanggan total dan biaya pelanggan total di mana, nilai pelanggan total adalah sekumpulan manfaat yang diharapkan oleh pelanggan dari produk atau jasa tertentu dan biaya pelanggan total adalah sekumpulan biaya yang diharapkan oleh konsumen yang dikeluarkan untuk mengevaluasi, mendapatkan, menggunakan dan membuang produk atau jasa. Sebagai suatu konsep nilai pelanggan adalah konsep yang konsisten bahwa keunggulan nilai yang ditawarkan hanya terdiri dari tiga yaitu kualitas produk, kualitas layanan dan nilai harga, sebagaimana didefinisikan Nauman (1995) Customer value is created when customer expectations in each of the three areas are met or exceeded. Only when all three are in harmony will customer value be maximized. Untuk menghadapi persaingan dan mendapatkan hasil bisnis berupa kemampulabaan, pertumbuhan dan nilai bagi pemegang saham maka tahap pertama yang perlu dilakukan oleh perusahaanperusahaan adalah memahami tuntutan pelanggan serta melakukan perancangan dan pengendalian kualitas yang efektif (Gale 1994). Dengan pemahaman terhadap kebutuhan pelanggan yang dipadukan dengan perancangan dan pengendalian kualitas yang efektif, maka akan diperoleh kualitas yang superior pada aspek-aspek yang berarti bagi pelanggan. Selanjutnya kualitas yang superior tersebut akan dirasakan oleh pasar apabila dikomunikasikan dengan pasar. Produk atau jasa yang diselenggarakan akan memiliki nilai jasa yang unggul apabila produk atau jasa tersebut hanya memerlukan cost of quality yang rendah untuk memproduksi ataupun menyampaikannya sehingga memiliki overall cost leadership.

Gaspers (Nasution, 2005) mengatakan bahwa kepuasan konsumen sangat bergantung kepada persepsi dan harapan konsumen. Adapun faktor-faktor yang mempengaruhi persepsi dan harapan konsumen antara lain (1) Kebutuhan dan keinginan yang berkaitan dengan hal-hal yang dirasakan konsumen ketika sedang mencoba melakukan transaksi dengan produsen produk. (2) Pengalaman masa lalu ketika mengkonsumsi produk dari perusahaan maupun pesaing-pesaingnya. (3)Pengalaman dari teman-teman. Engel et al (1994) mengatakan bahwa kepuasan adalah evaluasi paska konsumsi untuk memilih beberapa alternatif dalam rangka memenuhi harapan. Band (Nasution, 2005) mengatakan bahwa kepuasan tercapai ketika kualitas memenuhi dan melebihi harapan, keinginan dan kebutuhan konsumen. Sebaliknya, bila kualitas tidak memenuhi dan melebihi harapan, keinginan dan kebutuhan konsumen maka kepuasan tidak tercapai. 
Konsumen yang tidak puas terhadap barang atau jasa yang dikonsumsinya akan mencari perusahaan lain yang mampu menyediakan kebutuhannya.

Relationships adalah upaya menjalin relasi jangka panjang yang dilakukan oleh pihak dealer sepeda motor dengan para pelanggan. Relationship terletak pada kemampuan usaha dealer sepeda motor memahami kebutuhan dan keinginan pelanggan. Indikator berdasarkan Chaffey (2000) adalah 1) Identification adalah mempelajari karakteristik pelanggan secara rinci, 2) Individualization adalah menyesuaikan penawaran sesuai dengan karakteristik pelanggan, 3) Interaction adalah membangun dan mempertahankan komunikasi dua arah yang baik dengan pelanggan, 4)Integration adalah mengintegrasikan relasi/hubungan dengan pemahaman atas pelanggan yang dilakukan oleh para staff/pegawai, 5) Integrity adalah menjaga privasi/setiap pelanggan dan kepercayaan yang dibina dengan baik.Dengan demikian, secara singkat dapat dikatakan pemasaran relasional merupakan upaya pengenalan kepada setiap pelanggan secara lebih dekat, menciptakan komunikasi dua arah dengan konsumen, dan mengelola hubungan yang saling menguntungkan antara pelanggan dan perusahaan.

Buffa dan Porter (Wibisono 2006) menyatakan bahwa Pelayanan purna jual merupakan salah satu variabel penting dalam meningkatkan daya saing perusahaan yang harus diperhatikan guna merancang strategi bisnis perusahaan untuk memenangkan persaingan, di samping keunggulan pada harga atau biaya,kualitas, pengiriman, fleksibilitas, dan desain produk atau jasa.
Dalam jangka panjang, rancangan pelayanan purna jual membutuhkan pengembangan strategi, analisis kebutuhan pelanggan, dan analisis terhadap program dan posisi pesaing dalam memberikan layanan purna jual. Dalam aspek teknis, layanan purna jual membutuhkan rancangan yang menyangkut: Sistem dan prosedur untuk menarik produk atau jasa, sistem dan prosedur untuk jaminan klaim, sistem dan prosedur untuk mengontrol semua dokumen yang berkaitan dengan produk atau jasa yang ditawarkan, Layanan konsultasi, Perbaikan produk yang tidak memenuhi spesifikasi, penugasan pada pegawai yang harus merespons komplain pelanggan, pengembangan sistem pengkajianpelayanan purna jual (Wibisono 2006). Pelayanan purna penjualan adalah pelayanan yang diberikan oleh penjual setelah jual belidan setelah penyerahan barang dan jasa (Kotler 2009). Dukungan purna jual terutama yang berkaitan dengan waktu penyerahan dan bantuan yang diberikan, mencakup beberapa hal berikut: (a) Kecepatan penyerahan, berkaitan dengan lamanya waktu antara waktu pelanggan memesan produk dan waktu penyerahan produk itu; (b) Konsistensi, berkaitan dengan kemampuan memenuhi jadwal yang dijanjikan; (c) Tingkat pemenuhan pesanan, berkaitan dengan kelengkapan dari pesananpesanan yang dikirim; (d) Informasi, berkaitan dengan status pesanan; (e) Tanggapan dalam keadaan darurat, berkaitan dengan kemampuan menangani permintaan-permintaan nonstandar yang bersifat tiba-tiba; (f) Kebijaksanaan pengembalian, berkaitan dengan prosedur menangani barang-barang rusak yang dikembalikan pelanggan (Gaspersz 2002). 


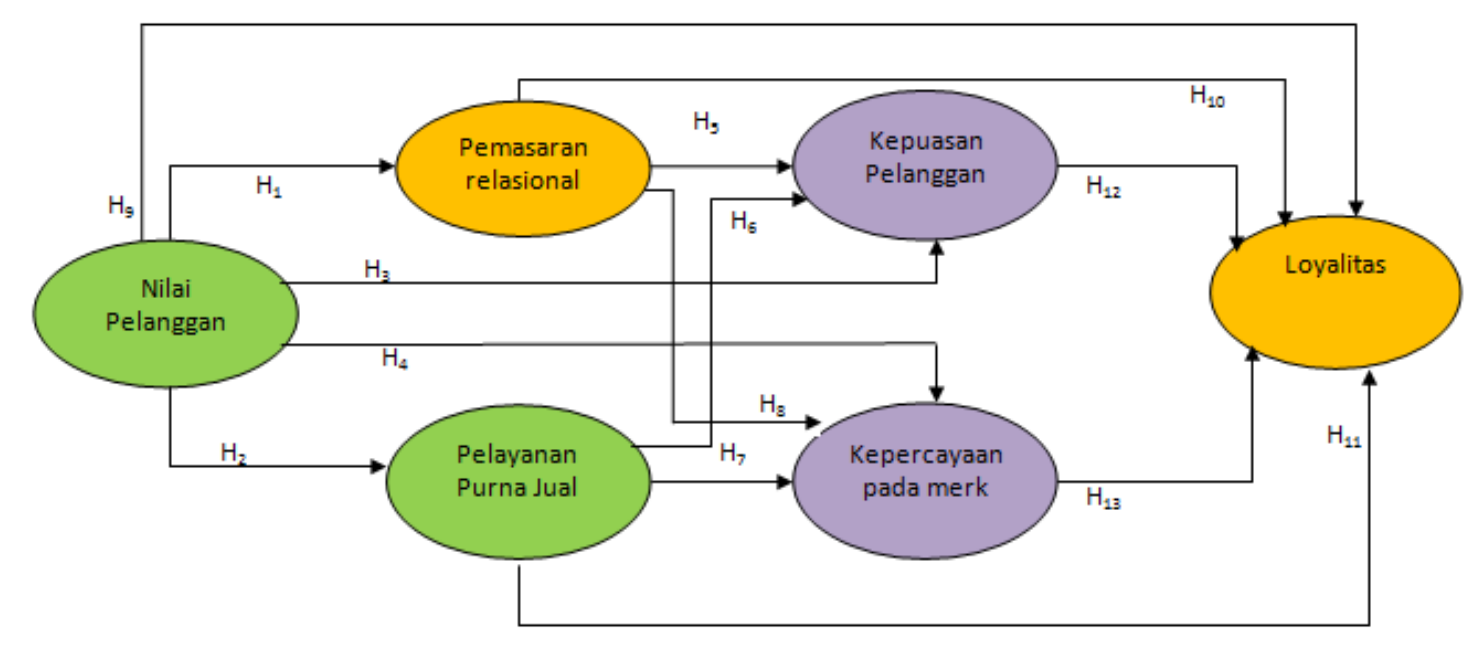

Sumber; Kotler (2000:12), Chauduri \& Holbrook (2001), Chaffey, et al. (2000:37)

Gambar 1. Kontruksi Model yang diuji

Kepercayaan merupakan faktor yang sangat penting dalam mengubah pembeli atau konsumen menjadi pelanggan pertama kali. Konsumen yang percaya pada suatu merek, cenderung akan mempercayakan masalahnya pada merek tersebut. Kepercayaan konsumenterhadap merek (brand trust) akan berdampak terhadap kesetiaan sikap ataupun perilaku konsumen terhadap suatu merek (Chauduri \& Holbrook 2001). Kepercayaan merek adalah kepercayaan konsumen bahwa merek yang diinginkan dapat diandalkan, memberikan jaminan tidak merugikan dan kinerjanya sangat berharga atau sangat bermanfaat.

Kaitan antar variabel yang diteliti yang disajikan dalam model konseptual penelitian ini merupakan penegasan dan memperlengkapi beberapa penelitian terdahulu yang telah dilakukan oleh beberapa peneliti. Tri Wahyu Herjuna, (2006) menjelaskan bahwa terdapat pengaruh yang signifikan nilai pelanggan terhadap kepuasan dan kesetiaan pelanggan (PT.Oval Engenering Indonesia).

Ferry Kurniawan dan Nawazirul Lubis (2013) menyatakan bahwa pemasaran relasional dan layanan purna jual berpengaruh positif dan signifikan terhadap kepuasan pelanggan pada PT.Astra Internasional Izusu Semarang. Sementara itu Aprilian Wulan dkk (2014), menjelaskan bahwa pengaruh langsung nilai pelanggan terhadap loyalitas lebih besar dibanding pengaruh tidak langsung, melalui kepercayaan pada merek pada pembeliaan notebook Thosiba, studi pada mahasiswa di UNDIP Semarang. Berdasarkan penelitian tersebut maka hipotesis yang bisa disusun adalah:

$\mathrm{H}_{1} \quad$ Nilai pelanggan berpengaruh signifikan terhadap pemasaran relasional

$\mathrm{H}_{2} \quad$ Nilai pelanggan berpengaruh signifikan terhadap layanan purna jual

$\mathrm{H}_{3} \quad$ Nilai pelanggan berpengaruh signifikan terhadap kepuasan pelanggan 
$\mathrm{H}_{4} \quad$ Nilai pelanggan berpengaruh signifikan terhadap kepercayaan pada merek

$\mathrm{H}_{5}$ Pemasaran relasional berpengaruh signifikan terhadap kepuasan pelanggan

$\mathrm{H}_{6}$ Layanan purna jual berpengaruh signifikan terhadap kepuasan pelanggan

$\mathrm{H}_{7}$ Layanan purna jual berpengaruh signifikan terhadap kepercayaan pada merek

$\mathrm{H}_{8}$ Pemasaran relasional berpengaruh signifikan terhadap kepercayaan pada merek

$\mathrm{H}_{9} \quad$ Nilai pelanggan berpengaruh signifikan terhadap loyalitas pelanggan

$\mathrm{H}_{10}$ Pemasaran relasional berpengaruh signifikan terhadap loyalitas pelanggan

$\mathrm{H}_{11}$ Layanan purna jual berpengaruh signifikan terhadap loyalitas pelanggan

$\mathrm{H}_{12}$ Kepuasan pelanggan berpengaruh signifikan terhadap loyalitas pelangan

$\mathrm{H}_{13}$ Kepercayaan pada merek berpengaruh signifikan terhadap loyalitas pelanggan

\section{METODE}

Populasi dalam penelitian ini adalah pelanggan sepeda motor di Kota Surakarta. Untuk menentukan ukuran sampel penelitian yang direkomendasikan adalah tidak kurang dari 50 observasi, dan disarankan ukuran sampel 100 atau lebih (Hair, dkk, 2006:9899). Dalam menentukan data yang akan diteliti teknik pengambilan sampling yang digunakan adalah dengan non probability sampling yaitu teknik yang tidak memberikan peluang atau kesempatan sama bagi setiap unsur atau anggota populasi untuk dipilih menjadi sampel. Dengan salah satu metodenya adalah accidental sampling artinya sampel dengan memilih pelanggan siapa yang kebetulan ada/dijumpai oleh peneliti.

Dalam model penelitian ini, peubah (variable) terdiri dari peubah eksogen dan peubah endogen. Peubah eksogen adalah nilai pelanggan. variabel endogen meliputi loyalitas. Variabel mediasi meliputi pemasaran relasional, pelayanan purna jual, kepuasan pelanggan, kepercayaan pada merk.

Nilai pelanggan (NIP) diukur dengan indikator kualitas pelayanan, produk, dan harga. Pemasaran relasional (PER) diukur dengan indikator Identification, Individualization, Interaction, Integration, dan Integrity. Kepuasan pelanggan (KEP) diukur dengan indikator minat beli ulang, terpenuhi kebutuhan, dan agen promosi. loyalitas (LOY) diukur dengan indikator memanfaat layanan, menyatakan hal positif, dan transaksi berulang ulang.

Pelayanan purna jual (PUJ) (Barata, 2003) diukur dengan indikator ketersediaan bengkel resmi, kemudahan mencari suku cadang, pelayanan karyawan, dan penanganan keluhan konsumen. Kepercayaan pada merk (KEM) (Rully Cahyadi, 2006) diukur dengan indikator Prediktabilitas Merek (Brand Predictability), Kesukaan pada Merek (Brand Liking), Kompetensi Merek (Brand Competence), Reputasi Merek (Brand Reputation), dan Kepercayaan pada Perusahaan (Trust in The Company). Teknik analisis yang digunakan untuk menguji model yang dikembangkan dalam penelitian adalah SEM (Structural Equation Modeling) (Hair et al, 1998; Ferdinand, 2013) 


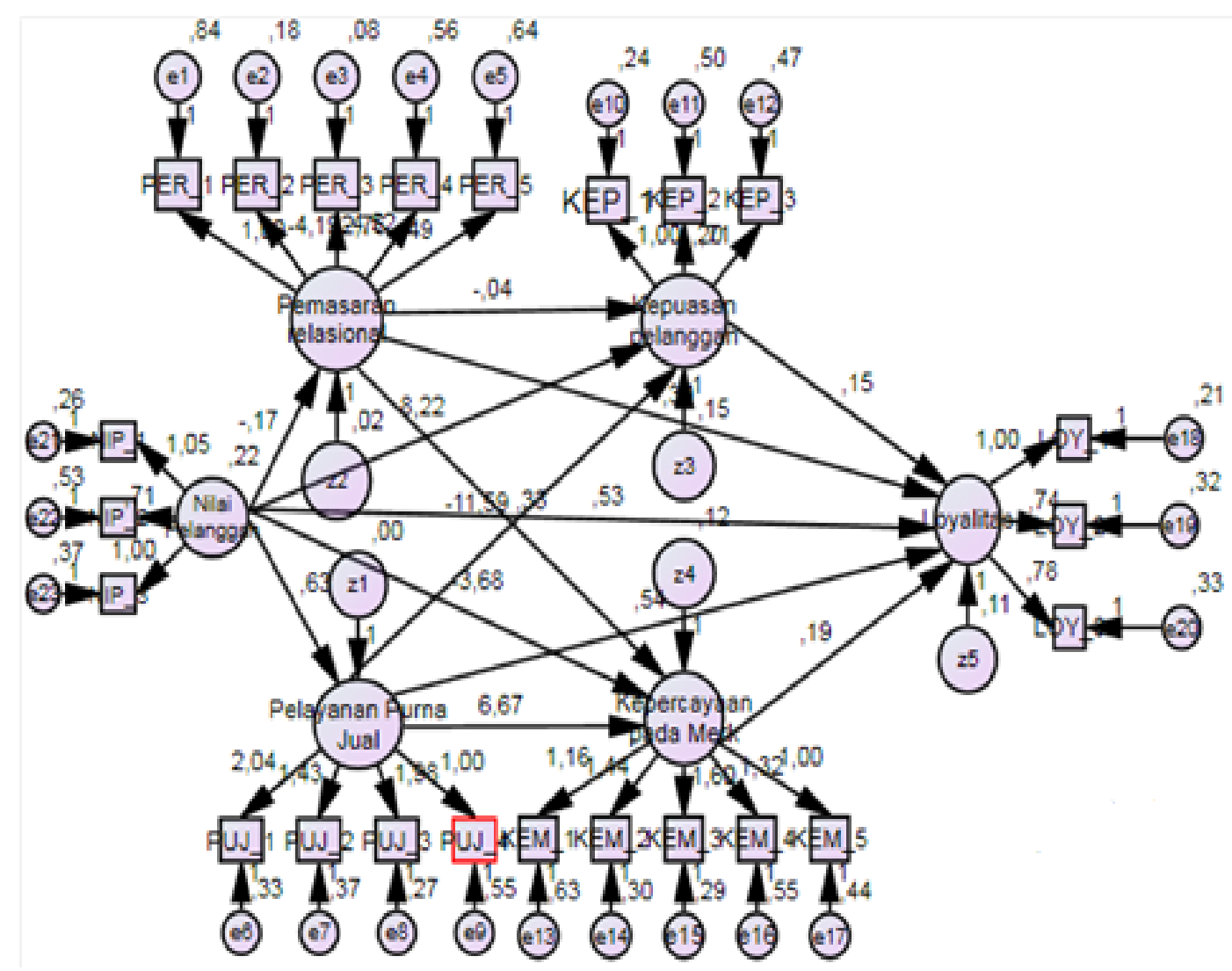

Gambar 2. Hasil Pengujian Model

\section{HASIL DAN PEMBAHASAN}

Hasil penelitian ini dilakukan terhadap 200 responden, dan sebagian besar respnden yang adalah responden yang berjenis kelamin wanita yaitu sebesar 62,5\%, sedangkan pria sebesar 37,5\%. Hasil penelitian ini juga menunjukan bahwa dari 200 responden, yang paling besar adalah responden yang berusia dewasa (35 s.d 45) yaitu sebesar $40 \%$. sedangkan responden terendah adalah yang berusia tertua ( 55 s.d 65) sebesar 3,5\%. Hal ini menunjukkan sebagian besar responden adalah angkatan produktif, sehingga ini dapat dijadikan dasar yang mendukung objektifitas penelitian

Hasil pengolahan data menunjukkan bahwa semua indicator (observed) adalah valid, hal ini ditandai dengan pengujian validitas dengan CFA yang menunjukan valid.
Pengujian validitas menunjukkan bahwa semua indikator (observed) layak digunakan sebagai indikator dari konstruk (laten variabel). Hasil pengolahan data menunjukan bahwa Composite reliability dengan nilai lebih dari 0,7 yang berarti bahwa internal consistency yang baik sehingga dapat dijelaskan bahwa variabel - variabel penelitian (konstruk) adalah reliabel, memiliki reliabilitas yang tinggi.

Analisis dalam penelitian ini adalah pengujian model dengan analisis Structural Equation Model (SEM) secara Full Model yang dimaksudkan untuk menguji model dan hipotesis yang dikembangkan dalam penelitian ini. Pengujian model dalam Structural Equation Model dilakukan dengan dua pengujian, yaitu uji kesesuaian model dan uji signifikansi kausalitas melalui uji 
Tabel 1. Model Structural Equation Modification

\begin{tabular}{cccc}
\hline Kriteria & Cut of value & Hasil & Evaluasi \\
\hline Chi Square & $<152,151$ & 350,000 & Tidak Baik \\
Probability & $>0,05$ & 0,016 & Tidak Baik \\
GFI & $>0,90$ & 0,932 & Baik \\
AGFI & $>0,90$ & 0,959 & Baik \\
TLI & $>0,95$ & 0,958 & Baik \\
CFI & $>0,95$ & 0,955 & Baik \\
RMSEA & $<0,08$ & 0,121 & Marginal \\
\hline
\end{tabular}

koefisien regresi. Hasil pengolahan data untuk analisis SEM terlihat pada Gambar 2.

Berdasarkan hasil pada grafik analisis full model dapat ditunjukkan bahwa model memenuhi kriteria fit. Walaupun hasil perhitungan uji chi-square pada full model memperoleh nilai chi-square sebesar 350 dengan $p=0,016$ yang artinya tidak fit, namun dari ukuran yang lain seperti dari GFI, AGFI, TLI dan CFI menunjukkan bahwa model fit (lihat Tabel 1). Hasil tersebut menunjukkan bahwa model memenuhi kriteria model goodness of fit

Setiap indikator pembentuk variabel laten sebagian besar memenuhi kriteria yaitu nilai CR di atas 1,96 dengan P lebih kecil dari pada 0,05 dan nilai lambda atau loading faktor yang lebih besar dari 0,5. Hasil tersebut dapat dikatakan bahwa indikatorindikator pembentuk variabel laten tersebut secara signifikan merupakan indikator dari faktor-faktor laten yang dibentuk. Dengan demikian, model yang dipakai dalam penelitian ini dapat diterima/valid. Hasil ini menyatakan bahwa model baik dapat diterima karena sesuai dengan empirisnya. Berdasarkan hasil diatas, maka faktor yang paling mempengaruhi loyalitas adalah layanan purna jual dan nilai pelanggan. Kedua variabel tersebut memberi kontribusi langsung yang paling besar terhadap loyalitas pelanggan.

Berdasarkan hasil nilai $p$-value (Tabel 2) tersebut maka simpulan yang diperoleh bahwa loyalitas pelanggan dipengaruhi secara signifikan oleh nilai pelanggan dan layanan purna jual. Bisnis penjualan sepeda motor dapat menggambarkan konsep bisnis dengan tingkat persaingan yang sangat ketat. Dilihat dari kualitas, setiap merek sepeda motor memiliki kualitas yang hampir sebanding, masing-masing ada kelebihan dan kekurangannya. Ditinjau dari tipe dan jenis motor, hampir ada kesamaan, baik yang matic maupun yang bukan matic. Ditinjau dari desain dan warna sangat bervariasi dan masing-masing memiliki daya tarik sendirisendiri. Umumnya, seorang pelanggan mengalami kesulitan untuk menentukan keputusan pembelian sebuah sepeda motor, sepeda motor Yamaha, Honda, Suzuki, Kawasaki dapat dikatakan memiliki daya tarik yang hampir sama. Hal ini dapat menggambarkan kondisi bisnis yang memiliki tingkat kompetitif yang sangat tinggi, yang sering membuat pelanggan sulit menentukan pembelian apalagi memiliki loyalitas pada suatu produk. Penelitian Ahmad Fauzi (UI, 2013) yang menyatakan bahwa nilai pelanggan berpengaruh positif dan signifikan terhadap loyalitas pelanggan (pada kasus 
Tabel 2. Regresion Weight (Full Model SEM)

\begin{tabular}{|c|c|c|c|c|c|c|c|}
\hline & & & Estimate & S.E. & C.R. & $P$ & Label \\
\hline PER & $<--$ & NIP &,- 172 & ,081 & $-2,125$ & ,034 & \\
\hline PUJ & $<--$ & NIP & ,634 & 137 & 4,636 & $* * *$ & \\
\hline KEP & $<--$ & NIP & 8,224 & 26,194 & ,314 &, 754 & \\
\hline KEM & $<--$ & NIP & $-3,683$ & 9,042 &,- 407 & ,684 & \\
\hline KEP & $<--$ & PER &,- 043 & ,344 &,- 125 & ,900 & \\
\hline KEM & $<--$ & PER & ,332 & 293 & 1,132 & ,257 & \\
\hline KEP & $<--$ & PUJ & $-11,589$ & 41,607 &,- 279 & ,781 & \\
\hline KEM & $<--$ & PUJ & 6,671 & 14,274 & ,467 & ,640 & \\
\hline LOY & $<--$ & NIP &, 531 & 7,416 & ,072 & ,043 & \\
\hline LOY & $<--$ & PER & 298 & ,355 & 840 & ,401 & \\
\hline LOY & $<--$ & PUJ &, 536 & 12,539 & ,043 & ,016 & \\
\hline LOY & $<--$ & KEP & 148 & 903 & 164 & 870 & \\
\hline LOY & $<--$ & KEM & 192 & ,542 & ,354 & ,723 & \\
\hline PER_1 & $<--$ & PER & 1,000 & & & & \\
\hline PER_2 & $<--$ & PER & $-4,191$ & 1,845 & $-2,271$ & ,023 & \\
\hline PER_3 & $<--$ & PER & $-4,517$ & 1,990 & $-2,269$ & ,023 & \\
\hline PER_4 & $<--$ & PER & $-2,762$ & 1,259 & $-2,193$ & ,028 & \\
\hline PER_5 & $<--$ & PER &,- 488 & ,436 & $-1,118$ & ,264 & \\
\hline PUJ_4 & $<--$ & PUJ & 1,000 & & & & \\
\hline PUJ_3 & $<--$ & PUJ & 1,983 & 401 & 4,944 & $* * *$ & \\
\hline PUJ_2 & $<--$ & PUJ & 1,430 & 314 & 4,557 & $* * *$ & \\
\hline PUJ_1 & $<--$ & PUJ & 2,041 & ,416 & 4,908 & $* * *$ & \\
\hline KEP_1 & $<--$ & KEP & 1,000 & & & & \\
\hline KEP_2 & $<--$ & KEP & 199 & ,114 & 1,753 & ,080 & \\
\hline KEP_3 & $<--$ & KEP & ,711 & 132 & 5,401 & $* * *$ & \\
\hline KEM_5 & $<--$ & KEM & 1,000 & & & & \\
\hline KEM_4 & $<--$ & KEM & 1,319 & 230 & 5,741 & $* * *$ & \\
\hline KEM_3 & $<--$ & KEM & 1,597 & 243 & 6,574 & $* * *$ & \\
\hline KEM_2 & $<--$ & KEM & 1,438 & 223 & 6,448 & $* * *$ & \\
\hline KEM_1 & $<--$ & KEM & 1,157 & 220 & 5,263 & $* * *$ & \\
\hline LOY_1 & $<--$ & LOY & 1,000 & & & & \\
\hline LOY_2 & $<--$ & LOY & ,738 & ,094 & 7,874 & $* * *$ & \\
\hline LOY_3 & $<--$ & LOY & ,780 & ,096 & 8,093 & $* * *$ & \\
\hline NIP_3 & $<--$ & NIP & 1,000 & & & & \\
\hline NIP_2 & $<--$ & NIP & ,713 & 138 & 5,153 & $* * *$ & \\
\hline NIP_1 & $<--$ & NIP & 1,049 & 135 & 7,764 & $* * *$ & \\
\hline
\end{tabular}

sepeda motor merek Honda). Penelitian Ricki Janitra (UM,2015) yang menyatakan bahwa layanan purna jual berpengaruh positif dan signifikan terhadap loyalitas pelanggan.
Pemasaran relasional, kepuasan pelanggan, kepercayaan pada merek kurang memberikan kontribusi yang kuat terhadap loyalitas pelanggan. Hal tersebut dapat terjadi karena beberapa pertimbangan, 
seperti sebagian besar dealer sebagai penjual sepeda motor telah menjalankan strategi pemasaran relasional ini dengan baik, mereka mendatangi pelanggan baik di rumah maupun di kantor atau ditempat tempat perdagangan bisnis seperti pasar,toko,mall. Pelanggan sudah mendapatkan informasi yang banyak tentang produk sepeda motor, namun hal itu tidak membuat pelanggan berminat untuk mengambil keputus an pembelian apalagi loyal.

Selain itu, kepuasan pelanggan boleh dikatakan sangat relatif, karena masing masing produk (Honda, Suzuki, Yamaha, Kawasaki) menawarkan kelebihan dan kekurangan masing masing, sehingga kepuasan pelanggan sangat dipengaruhi oleh unsur persepsi pelanggan. Pelanggan akan mengalami kepuasan menurut persepsi masing masing, dapat karena faktor desain,warna,irit bahan bakar atau yang lain, hal ini sangat subyektif.

Kepercayaan pada merek juga sangat ditentukan oleh kualitas dari produknya. Namun, merek sepeda motor seperti honda, suzuki,yamaha dan kawasaki dapat dikatakan memiliki kualitas merek yang hampir sama dan sangat kompetitiif. Sebagian pelanggan mengatakan bahwa honda lebih baik karena lebih irit bahan bakar, namun sebagian lainnya mengatakan bahwa suzuki lebih kuat dan stabil untuk dikendarai, hal ini menunjukan bahwa masing masing produk memiliki kelebihan yang dibutuhkan oleh pelanggan. Fakta penjualan menunjukan bahwa jumlah penjualan sepede motor tersebut hampir sama setiap tahunnya. Warungasep.net - (Data AISI) untuk bulan September ini, berikut data dari keselurahan ATPM: Honda (233.080 unit), Yamaha
(186.659 unit, Suzuki (12.321 unit), Kawasaki (12.324).

Penelitian atau studi tentang pasar sepeda motor ini dapat menggambarkan pasar persaingan monopolistik merupakan salah satu dari pasar persaingan tak sempurna. Di lihat dari struktur, pasar monopolistik lebih mendekati pada pasar persaingan sempurna (dicirikan dengan banyak perusahaan yang berpartisipasi di pasar, tanpa batasan masuk industri yang serius) tetapi perusahaan yang berpartisipasi di pasar tersebut menghasilkan produk yang berbeda karakteristik. Pasar monopolistik didefinisikan sebagai pasar dengan banyak produsen yang menghasilkan komoditas yang berbeda karakteristik (differentiated product) dan bisa disebut juga sebagai pasar yang banyak penjual, yang menawarkan satu jenis barang dengan diferensi produk yang berbeda-beda baik dari segi kualitas, bentuk dan ukuran. Dalam pasar persaingan monopolistik para konsumen merasakan adanya perbedaan karakteristik dari produkproduk yang dihasilkan oleh suatu perusahaan dengan produk-produk yang dihasilkan oleh perusahaan-perusahaan lainnya. Perbedaan produk dapat dilihat dari bentuk fisiknya seperti beda fungsi, bentuk ataupun kualitas. Perbedaan juga dapat dijumpai dalam kaitannya dengan merek, logo ataupun kemasan pada produk sepeda motor. Beberapa kekurangan dalam pasar monopolisti ini adalah: 1) Pasar monopolistik memiliki tingkat persaingan yang tinggi, baik dari segi harga, kualitas maupun pelayanan. Sehingga produsen yang tidak memiliki modal dan pengalaman yang cukup akan cepat keluar dari pasar, 2) Dibutuhkan modal yang cukup besar untuk masuk ke dalam 
pasar monopolistik, karena pemain pasar di dalamnya memiliki skala ekonomis yang cukup tinggi, 3) Pasar ini mendorong produsen untuk selalu berinovasi, sehingga akan meningkatkan biaya produksi yang akan berimbas pada harga produk yang harus dibayar oleh konsumen.Hasil penelitian memberikan temuan bahwa dalam konsep pasar persaingan monopolistik faktor nilai pelanggan (kualitas layanan, harga, produk) serta layanan purna jual menjadi faktor yang perlu mendapat perhatian yang serius karena akan memberi kontribusi yang besar terhadap penciptaan loyalitas pelanggan.

\section{SIMPULAN}

Model konseptual/ struktural yang diuji, yang menggambarkan pengaruh nilai pelanggan terhadap loyalitas, diuji dengan analisis SEM dan metode Goodness of fit, menyatakan bahwa model dapat diterima dan berarti ada kesesuaian antara model dengan faktor empiris dalam penelitian ini. Model struktural menunjukan bahwa nilai pelanggan dan layanan purna jual memberikan kontribusi langsung yang signifikan terhadap penciptaan loyalitas pelanggan. Dalam konsep pasar persaingan monopolistik faktor nilai pelanggan (kualitas layanan, harga, produk) serta layanan purna jual menjadi faktor yang perlu mendapat perhatian yang serius karena akan memberi kontribusi yang besar terhadap penciptaan loyalitas pelanggan.

Keterbatasan penelitian terletak pada obyek, karena penelitian ini hanya mengambil obyek pelanggan sepeda motor di kota surakarta dan pendekatan penelitian hanya dilakukan sebatas pendekatan kuantitatif, belum dilakukan pendekatan secara kualitatif sehingga perlu adanya pendekatan lebih lanjut, khususnya secara kualitatif, untuk menggali secara mendetail dan menjawab permasalahan loyalitas pelanggan pada konsep pasar monopolistik. Oleh karena itu disarankan (1)Bagi peneliti selanjutnya, perlu dilakukan penelitian lanjutan untuk mengkaji ulang dengan obyek penelitian yang berbeda terkait faktor yang memberi pengaruh loyalitas pelanggan.

\section{DAFTAR PUSTAKA}

Ali, H. (2008). Marketing. Yogyakarta: Media Utama.

Chaffey, D. (2000). Internet Marketing: Strategy, Implementation and Practice. London: Pearson Educating Limited.

Chaudhuri, A. \& Holbrook, M.B. (2001) The Chain of Effects from Brand Trust and Brand Affect to Brand Performance: The Role of Brand Loyalty. Journal of Marketing, 65(2), 81-93.

Chen, S.C. (2015). Customer value and customer loyalty: Is competition a missing link? Journal of Retailing and Consumer Services, 22, 107-116. http://doi.org/10.1016/j.jretconser.2014 .10 .007

Engel, J.F., Black, R.D., \& Miniard, P.W. (1994). Consumer Behavior, 6th ed. The Dryden Press, Chicago.

Ferdinand, A. (2006). Structural Equation Modelling Dalam Penelitian Manajemen Edisi 4, Badan Penerbit Universitas Diponegoro, Semarang

Gale, B. (1994). Managing Customer Value. New York : Prentice The Free Press.

Garbarino \& Johnson. (1999). The Different Roles of Satisfaction. Journal of Marketing. April. 1999

Gasperz, V. (1997). Manajemen Kualitas: Penerapan Konsep-Konsep Kualitas 
dalam Manajemen Bisnis Total. Penerbit PT Gramedia Pustaka Utama,Jakarta

Hair, J.R., J.F., Anderson, R.E., Tathan, R.L., \& Black, W.C., (1998), Multivariate Data Analysis, 5th ed. Upper Saddle River, Prentice Hall, Inc, New Jersey.

Kiran, K., \& Diljit, S. (2011). Antecedents of customer loyalty: Does service quality suffice?. Malaysian Journal of Library and Information Science, 16(2), 95-113

Kotler, P. \& Keller, K.L. (2009). Manajemen Pemasaran, edisi 13. Jilid 2. Jakarta

Kurniawan, F. (2013). Pengaruh Relationship Marketing dan Layanan Purna Jual terhadap kepuasan pelanggan PT.Astra Internasional Izusu Semarang. Jurnal Administrasi dan Bisnis, 2(1), Maret 2013

Nasution, M.N. (2001). Manajemen Mutu Terpadu (Fotal Quality Management), Jakarta: Ghalia Indonesia.

Naumann \& Giel, K. (1995). Customer Satisfaction Measurement and Management. Cincinati. Ohio: Thomas Execuitve Press.

Putra, A.M. \& Rahmawati, P. (2012). Pengaruh Ekuitas Merek Terhadap Loyalitas Pelanggan Yang Dimediasi Oleh Kepuasan Pelanggan (Studi Kasus: Pengguna Sepeda Motor Merek Honda di Kota Yogyakarta). Jurnal Manajemen Bisnis Indonesia, Volume 1 Edisi 1,UNY Jojakarta

Quach, T. N., Thaichon, P., \& Jebarajakirthy, C. (2016). Internet service providers' service quality and its effect on customer loyalty of different usage patterns. Journal of Retailing and Consumer Services, 29, 104-113. http://doi.org/10.1016/j.jretconser.2015 .11 .012

Rafig, M. (2009). Pengaruh kepercayaan pelanggan pada merek terhadap loyalitas merek. Jurnal Fakultas Ekonomi: OPTIMAL, 3(1)

Rasheed, F.A., \& Abadi, M. F. (2014). Impact of Service Quality, Trust and Perceived Value on Customer Loyalty in Malaysia Services Industries. Procedia - Social and Behavioral Sciences, 164(August), 298304. http://doi.org/10.1016/j.sbspro. 2014.11.080

Rizka, L.A. (2010). Pengaruh relationship marketing terhadap loyalitas pelanggan sepeda motor Yamaha (studi pada mahasiswa Fakultas Ekonomi Universitas Negeri Malang). Jurnal MULOK, Universitas Negeri Malang

Rizkiardi, M.Y. (2013). Pengaruh persepsi layanan purna jual terhadap loyalitas pengguna Toyota Avanza di bekas. Jurnal Ilmiah Universitas Bakrie, 1(3).

Saparso \& Jesfer. (2010). Pengaruh kepuasan pelanggan dan kinerja produk terhadap loyalitas pelanggan sepeda motor Honda. Jurnal Ilmiah Manajemen Bisnis, 10(1), 31-46.

Wibisono, D. (2006). Manajemen Kinerja. Jakarta: Erlangga. 